\title{
PERUBAHAN FLUKTUATIF STRUKTUR EKONOMI INDONESIA PADA MASA PANDEMI COVID-19
}

\author{
Herlina \\ STAI Diniyah Pekanbaru \\ Jl. Kuau No. 01 Sukajadi Pekanbaru \\ herlina@diniyah.ac.id
}

DOI: 10.46781/al-mutharahah.v17i2.142

\begin{abstract}
Economic growth in Indonesia has experienced fluctuating changes in 2020, especially entering the Covid-19 pandemic. The subjectivity factor greatly affects Indonesia's economic growth. The important factors that play a role are the low income per person of the population and the large carry-over of the workforce which takes place under pressure from very vulnerable external conditions, which is reflected in the high burden of foreign debt. This is due to being too dependent on imported products which have eroded labor productivity and the empowerment of natural resources has greatly decreased. Economic growth has declined sharply with the spread of the Covid-19 virus which began to enter Indonesia in the second quarter of 2020. The Covid-19 pandemic has greatly affected the movement of the Indonesian economy which tends to decline. This study uses a qualitative method with a descriptive level of explanation, centralized data collection inaccurate social media reports from reliable informant sources, namely the statement of the Minister of Finance Sri Mulyani. The presentation of the research results that in the first quarter (the period from January 2020 to March 2020) economic growth was recorded at a safe rate of plus $2.97 \%$, in the second quarter (April 2020 to June 2020) showed a slump in economic growth, namely minus 5, $32 \%$, there was a significant change, namely a slight increase but still a minus occurred in the third quarter (July 2020 to September 2020) which was minus 1\% to minus $2.9 \%$. The negative conditions in the last two quarters resulted in the Indonesian economy falling into a recession. The government must make various important efforts to overcome this recession, namely by deregulating, reducing loan interest rates, increasing interest rates or public savings margins, promoting non-oil and gas exports, expanding job opportunities, restructuring processes due to the still gloomy external situation, increasing taxes, reduction of imported products, handling of the informal sector.
\end{abstract}

Keywords: Change; Economic Growth; Pandemic; Covid 19

\begin{abstract}
Abstrak
Pertumbuhan ekonomi di Indonesia mengalami perubahan naik turun di tahun 2020, terutama memasuki masa pandemi Covid-19. Faktor subjektifitas sangat mempengaruhi pertumbuhan ekonomi Indonesia. Faktor penting yang berperan adalah rendahnya pendapatan per jiwa penduduk dan besarnya carry over angkatan kerja yang berlangsung di bawah tekanan kondisi eksternal yang sangat rawan, yakni tercermin pada tingginya beban utang luar negeri. Hal ini disebabkan terlalu tergantung pada produk impor yang menggerus produktifitas tenaga kerja dan pemberdayaan sumber daya alam menjadi sangat menurun. Pertumbuhan ekonomi semakin merosot tajam dengan adanya penyebaran virus Covid-19 mulai memasuki negara Indonesia di kuartal II 2020. Masa pandemi Covid-19 sangat mempengaruhi gerak perekonomian Indonesia yang cenderung menurun. Penelitian ini menggunakan metode kualitatif dengan tingkat eksplanasi deskriptif, pengambilan data terpusat di laporan media sosial yang akurat dari sumber informan terpercaya, yakni pernyataan Menteri Keuangan Sri
\end{abstract}


Mulyani. Pemaparan hasil penelitian bahwa pada kuartal I (periode bulan Januari 2020 sampai dengan Maret 2020) tercatat pertumbuhan ekonomi di angka yang masih aman yaitu plus 2,97\%, pada kuartal II (April 2020 sampai dengan Juni 2020) menunjukkan keterpurukan pertumbuhan ekonomi yakni minus $5,32 \%$, terjadi perubahan cukup signifikan yakni sedikit meningkat tetapi masih minus terjadi di kuartal III (Juli 2020 sampai dengan September 2020) adalah sebesar minus $1 \%$ sampai dengan minus 2,9\%. Kondisi minus pada kedua kuartal terakhir mengakibatkan keadaan perekonomian Indonesia jatuhdalam posisi resesi. Pemerintah harus melakukan berbagai upaya penting untuk menanggulangi keadaan resesi ini adalah dengan melakukan deregulasi,penurunan suku bunga pinjaman, meningkatkan suku bunga atau margin simpanan masyarakat, penggalakan ekspor non migas, perluasan kesempatan kerja, proses restrukturisasi akibat situasi eksternal yang masih suram, peningkatan pajak, pengurangan produk impor, penanganan sektor informal.

Kata Kunci: Perubahan; Pertumbuhan Ekonomi; Pandemi; Covid 19.

\section{A. PENDAhULUAN}

Proses pembangunan bergantung kepada pertumbuhan ekonomi dan berbagai perubahan di segala bidang kehidupan seiring dengan aspirasi masyarakat yang selalu berkembang. Pembangunan tanpa menghasilkan expansion of freedom mengakibatkan terjadinya pemusatan kemakmuran. Adanya tuntutan keseimbangan, keselarasan dan keserasian di berbagai kehidupan dan berbagai aspek ekonomi sehingga terbentuk landasan kokoh untuk kesinambungan pembangunan jangka panjang yang berkeadilan. Perekonomian domestik yang kokoh harus terjalin dan menyatu secara interelasi dan interdepedensi dengan bermacam pengaruh lingkungan eksternal, yang mengakibatkan adanya ancaman dan peluang dalam sistem ekonomi. ${ }^{1}$

Kebijakan dan program penanggulangan kemiskinan melalui Inpres Nomor 5 tahun 1993 merupakan arah baru dalam melaksanakan pembangunan pedesaan yang mengakar pada kekuatan rakyat. Pertumbuhan kegiatan produktif dirangsang melalui program IDT (Desa Tertinggal) dengan cara memberikan bantuan modal kerja dan menyediakan tenaga pendamping. Pengarahan kedua "intervensi" tersebut kepada pengembangan sumber daya manusia di pedesaan, penciptaan lapangan pekerjaan dan peluang usaha, pemilihan berbagai jenis usaha sesuai wilayah, penciptaan kelembagaan dan system pelayanan, keterlibatan banyak pihak dalam meningkatkan ketahanan ekonomi rakyat. ${ }^{2}$

Pemerataan ekonomi di Indonesia akan terwujud dengan dilakukan secara dinamis, diibaratkan pembagian "kue" yang sama dan dirasakan adil bagi semua orang. Laju pertumbuhan ekonomi dalam setiap periode dan dekade tidak selalu sama, konsisten dan harmonis. Berbagai sektor harus saling mendukung satu sama lain, seperti sektor pertanian dan industri yang masih menduduki peringkat penting dalam pertumbuhan ekonomi negara. Strategi pembangunan negara harus bersifat "menetes ke bawah" memadai mengatasi kemiskinan struktural. Hal terpenting adalah arah dan penyebaran pertumbuhan dalam mempengaruhi tingkat pertumbuhan ekonomi negara. ${ }^{3}$

Terdapat beberapa permasalahan yang masih konsisten dalam memajukan perekonomian rakyat Indonesia, yakni motivasi masyarakat dalam mengatasi kebutuhan dan kesulitan hidup rutinitas yang masih rendah, masih banyak bidang usaha yang mengalami kegagalan karena kurangnya ketrampilan di bidangnya, sarana dan prasarana penunjang masih sangat kurang terutama di desa terpencil, dukungan dana pemerintah yang belum menyebar

${ }^{1}$ Faisal Basri. Perekonomian Indonesi, Tantangan dan Harapan bagi Kebangkitan Indonesia. (Jakarta: Erlangga, 2002). Hlm. 1. Hlm. vii..

${ }^{2}$ Mubyarto.Pemberdayaan Ekonomi Rakyat, laporan kaji tindak program IDT. (Jakarta: Bappenas, 1999).

${ }^{3}$ Sjahrir.Ekonomi, enak dibaca dan perlu.(Jakarta: Pustaka Utama Grafiti, 1994) Hlm. 19-20. 
rata disegala bidang dan daerah. Penanggulangan keemiskinan rakyat yang berimbas kepada pertumbuhan ekonomi negara harus dapat diatasi dengan saling bahu membahu dan saling support antara masyarakat, pejabat dan lingkungan pemerintah. ${ }^{4}$

Beberapa fenomena yang terurai diatas masih mempengaruhi pertumbuhan ekonomi di tahun 2020 dan ditambah gejolak penyebaran virus Covid-19 yang akhir menyebabkan kondisi pandemi menjadikan keterpurukan perekonomian mulai terasa di kuartal II tahun ini, memicu untuk melakukan analisis dalam penelitian berdasarkan data dan realita yang ada, dengan judul "Perubahan Fluktuatif Struktur Ekonomi Indonesia Pada Masa Pandemi Covid-19".

\section{B. METODE PENELITIAN}

Penelitian yang dilaksanakan tergolong kualitatif yang menggunakan data paparan dan ditinjau dari tempat penelitian tergolong kajian referensi, analisis data yang didukung keilmiahan dengan menggunakan literatur/kepustakaan berupa buku, jurnal dan sumbersumber yang relevan.Berdasarkan tingkat eksplanasinya, penelitian ini termasuk deskriptif. Dari pengukuran dan analisis data, penelitian ini bentuk verbal dan dianalisis tanpa menggunakan teknik statistik. Penelitian dilakukan dengan pengambilan data akurat di internet, dengan waktu penelitian di minggu I dan II bulan Oktober2020. Penelitian telah dilakukan analisa keabsahan data melalui uji kredibilitas (credibility) dan hasil penelitian dapat ditransfer ke wilayah lain dengan melakukan uji transferabilitas (transferability).

\section{PEMBAHASAN}

1. Pertumbuhan Ekonomi

Pertumbuhan ekonomi yang diiringi pemerataan pendapatan akan membantu mempercepat penurunan kemiskinan di suatu negara. Tingkat pertumbuhan ekonomi di negara berkembang yang memiliki lesenjangan pendapatan yang tinggi cenderung akan selalu menurun. Dalam pengertian lain bahwa kesenjangan ekonomi yang lebar mempunyai dampak negatif terhadap pertumbuhan ekonomi. ${ }^{5}$

Di dunia modern sangat membutuhkan pertumbuhan ekonomi yang cepat dan meningkat. Di negara-negara yang telah maju seperti Eropa dan Amerika telah memiliki ratarata per kapita yang lebih tinggi dibandingkan negara-negara di Asia, Afrika.Pada masyarakat perkotaan industri telah muncul pandangan teknologis yang sangat produktif. Pembangunan modern yang cukup pesat telah menimbulkan berbagai macam kesulitan bagi "masyarakat makmur" di Barat, namun menciptakan jurang yang semakin lebar di antara beberapa standar hidup berbagai bangsa yang kaya dan miskin. Pola pembangunan yang berbeda ini merupakan hasil dari berbagai keadaan sejarah, kebudayaan negara tersebut, yang menjadikan sebuah kekuatan besar dan kondisi yang khas bagi proses pertumbuhan ekonomi. Berbagai kekuatan yang terselubung ini berkenaan dengan jumlah, mutu dan susunan berbagai sarana produksi dasar suatu negara. ${ }^{6}$

Pertumbuhan ekonomi akanmeningkat dengan kecepatan rata per kapita penduduk yang tinggi. Dalam menghadapi perubahan ekonomi dan sosial harus bersikap optimis dan positif sehingga menghasilkan transformasi struktur ekonomi yang baik dan harmonis. Perubahan struktur ekonomi selalu berlangsung setiap tahunnya dengan pengalokasian sumber-sumber ekonomi. Skala prioritas pertumbuhan ekonomi yang harus lebih menyebar

\footnotetext{
${ }^{4}$ Mubyarto.Pemberdayaan Ekonomi Rakyat, laporan kaji tindak program IDT. (Jakarta: Bappenas, 1999). Hlm. 5,13-15.

${ }^{5}$ Eka Sastra. Kesenjangan Ekonomi. Mewujudkan Keadilan Sosial di Indonesia. (Bandung: PT. Mizan Publika, 2017).Hlm. 103.

${ }^{6}$ Richard T. Gill. Ekonomi Pembangunan Dulu dan Sekarang.(Jakarta: Ghalila, 1983). Hlm. 11-12.
} 
rata dan tingkat pertumbuhan tetap tinggi adalah dengan meniadakan berbagai oligopoli monopoli dan harga proyek yang di mark up. Pertumbuhan ekonomi akan meningkat dengan memperhatikan efisiensi ekonomi sehingga penerimaan pajak meningkat, pemasukan zakat dan wakaf dapat tersalur/didistribusikan merata dan teratur ke berbagai program bidang kesejahteraan dan daerah. ${ }^{7}$

Pertumbuhan ekonomi akan terwujud dengan cara melakukam pembenahan manajemen pembangunan dan pemerintahan, reformasi sistem pengambilan keputusan, pembentukan program pengembangan kelembagaan yang menopang peningkatan dinamika perekonomian yang sehat. Pemberantasan bentuk praktek monopoli dan penguasan usaha terintegrasi dari hulu ke hilir serta berbagai prakteklain yang banyak merugikan rakyat, terutama pemonopoli bebas menentukan volume produksi yang rendah untuk mendapatkan harga penjualan yang lebih tinggi.Langkah utama dan konkrit yang harus dilakukan adalah membuka akses kesempatan (access of opportunity) seluas-luasnya kepada semua pihak terhadap semua jenis usaha yang mendorong peningkatan kompetensi dan daya saing. Kredibilitas pemerintah harus dijaga dan dipertahankan untuk meningkatkan kepercayaan (trust) masyarakat terhadap setiap kebijakan yang dikeluarkan pemerintah. ${ }^{8}$

Beberapa faktor yang berpengaruh dalam mengembangkan ekonomi rakyat, yakni tambahan modal ke pelosok daerah, perbaikan kualitas sumber daya manusia, pengenalan teknologi tepat guna, memperkenalkan berbagai inovasi sosial ke daerah, motivasi kepada semua jajaran masyarakat untuk mengembangkan perekonomian. Pendekatan dinas pengembangan dan pertumbuhan ekonomi rakyat dengan memperhatikan kemajuan kebutuhan masyarakat dari kebutuhan dasar (pangan) keluarga. ${ }^{9}$

Faktor eksternal sangat mempengaruhi pertumbuhan ekonomi yang tinggi. Peningkatan investasi portofolio melalui pembelian saham di pasar modal memiliki imbas yang cukup signifikan terhadap pertumbuhan ekonomi Indonesia. Pembelian saham merupakan sumber dana bagi perusahaan yang masuk bursa untuk memperluas kegiatan usaha tanpa perlu meinjam uang di bank. Kunci keberhasilan dengan tingkat pertumbuhan ekonomi yang tinggi adalah selalu memperhatikan dan mengedepankan sikap birokrasi pusat yang membagi kekuasaan ke daerah-daerah.Kebijakan pemerintah dalam menentukan dan memainkan politik perindustrian sangat mempengaruhi perkembangan dan pertumbuhan ekonomi negara. ${ }^{10}$ Dalam upaya menciptakan pertumbuhan ekonomi menuju masyarakat adil dan makmur, Indonesia memerlukan dana pembiayaan yang besar untuk pembangunan secara nasional. Sumber pembiayaan dari dlaam negeri adalah berupa tabungan masyarakat, swasta dan pemerintah, sedangkan yang berasal dari luar negeri yaitu berupa bantuan hibah (grant), pinjaman luar negeri dan penanaman modal asing. Negara berkembang seperti Indonesia memiliki sumber pembiayaan berupa pinjaman atau utang luar negeri yang sangat memegang peranan penting dalam pembangunan nasional.Indonesia mengalokasikan sebagian besar pinjaman luar negeri untuk kebutuhan pemerintah, hanya jumlah kecil untuk keperluan kalangan swasta. Pinjaman luar negeri sebagai sumber pembiayan pembangunan dalam anggaran pengeluaran pembangunan.Ketidak tersedianya tabungan pemerintah dalam

${ }^{7}$ Sjahrir.Ekonomi, enak dibaca dan perlu. (Jakarta: Pustaka Utama Grafiti, 1994) Hlm. 21-22.

${ }^{8}$ Faisal Basri. Perekonomian Indonesi, Tantangan dan Harapan bagi Kebangkitan Indonesia. (Jakarta: Erlangga, 2002). Hlm.37-38. Hlm. 27-29

${ }^{9}$ Mubyarto.Pemberdayaan Ekonomi Rakyat, laporan kaji tindak program IDT. (Jakarta: Bappenas, 1999).

${ }^{10}$ Sjahrir.Ekonomi, enak dibaca dan perlu. (Jakarta: Pustaka Utama Grafiti, 1994) Hlm. 39. 
membiayai pengeluaran pembangunan pemerintah mengakibatkan terjadinya peningkatan pinjaman luar negeri setiap tahun. ${ }^{11}$

Anggaran Pendapatan dan Belanja Negara (APBN) merupakan alat utama pemerintah untuk mensejahterakan rakyat dan alat pemerintah dalam mengelola perekonomian negara.APBN bukan hanya sebagai menyangkut keputusan ekonomi tetapi juga berkenaan dengan keputusan politik. Dalam konteks ini, DPR dengan hak legilasi, penganggaran dan pengawasan yang dimilikinya perlu lebih berperan dalam mengawal APBN sehingga APBN dapat berjalan dengan efektif menjadi instrumen dalam mensejahterakan rakyat dan mengelola perekonomian negara. ${ }^{12}$

\section{Perubahan Fluktuatif Struktur Ekonomi}

Ekonomi modern mengalami pertumbuhan seiring dengan adanya ledakan bervariasi dalam instrumen pembayaran dan investasi. Prinsip yang berlaku adalah semakin tinggi resiko maka semakin tinggi imbal hasil (high risk high returns). Resiko merupakan fungsi dari ketidakpastian, sedangkan dunia melakukan jual beli ketidakpastian tersebut. Semakin tinggi ketidakpastian tersebut dijual maka semakin besar masyarakat berharap menarik keuntungan. Pada tahap ini, ekonomi bergerak menuju ekonomi kasino, yakni ekonomi berbahan bakar naluri spekulasi. Sistem ekonomi kapitalisme sedang menghadapi tantangan terbesar yaitu mencari keseimbangan baru agar komponen nurani tidak tersingkir oleh naluri. Sistem ekonomi yang salah merupakan persemaian benih terorisme ekonomi yang lebih berbahaya. Pada titik ini harus kuat melakukan refleksi dan introspeksi dengan upaya memecahkan persoalan besar yang selalu berakar pada kekuatan kolektif bangsa. ${ }^{13}$

Perubahan struktur ekonomi secara fluktuatif banyak dipengaruhi faktor internal dan eksternal. Salah satu cara meningkatkan struktur ekonomi Indonesia yakni mengurangi utang luar negeri, dengan menerbitkan surat utang pemerintah di dalam negeri dalam bentuk obligasi. Perbaikan dalam pemberian subsidi pemerintah harus selalu dievaluasi dan dimonitor dengan baik, harus tertuju sasaran kepada kalangan yang kurang atau tidak mampu. Pemerintah harus dapat bertindak cepat dalam mengkoreksi kemerosotan atau persepsi pelaku ekonomi karena akan berdampak kepada perlambatan pertumbuhan ekonomi negara. ${ }^{14}$

Mencapai pertumbuhan ekonomi yang stabil dan terarah hendaknya dimulai dari pedesaan atau pelosok daerah dengan meningkatkan peran pemberdayaan aparat pedesaan, terutama dalam aspek ekonomi. Aparat pedesaan harus menjadi panutan dalam menggerakkan pembangunan daerahnya, termasuk dalam membina kesejahteraan masyarakat. Pembinaan penduduk di pelosok daerah bukan pekerjaan yang mudah dan instan. Peran aparat pedesaan sangat diharapkan dalam merubah sikap masyarakat yang cenderung apatis menjadi masyarakat yang mampu menerima perubahan dalam meningkatkan kesejahteraan hidup. ${ }^{15}$

Salah satu yang mempengaruhi perekonomian Indonesia adalah fungsi anggaran di pemerintahan karena berdampak terhadap kontraksi penerimaan, seperti berkurangnya kemampuan masyarakat dalam berkonsumsi dan menabung akan berakibat kepada berkurangnya potensi investasi dan keuntungan. Dua pertiga penerimaan anggaran di pemerintahan berasal dari pajak dan pungutan pemerintah lainnya. Restrukturisasi yang terpenting adalah harus terfokus pada anggaran. Pergeseran peran utama luar negeri, pajak

\footnotetext{
${ }^{11}$ Rustian Kamaluddin.Beberapa Aspek Perkembangan Ekonomi Nasional Dan Internasional.(Jakarta: Lembaga Penerbit Fakultas Ekonomi Universitas Indonesia, 1989). Hlm. 33,34, 39.

${ }^{12}$ Julius R. Latumaerissa. Perekonomian Indonesia dan Dinamika Ekonomi Global. (Jakarta: Mitra Wacana Media, 2015). Hlm. 223.

${ }^{13}$ Hendrawan Supratikno. Ekonomi Nurani vs Ekonomi naluri. (Jakarta: Yayasan Pustaka Obor, 2011). Hlm. 51,54, 71

${ }^{14}$ Faisal Basri. Perekonomian Indonesi, Tantangan dan Harapan bagi Kebangkitan Indonesia. (Jakarta: Erlangga, 2002). Hlm. 57.

${ }^{1515}$ Mubyarto.Pemberdayaan Ekonomi Rakyat, laporan kaji tindak program IDT. (Jakarta: Bappenas, 1999).Hlm. 104, 114.
} 
dan penerimaan migas secara keseluruhan sangat membatasi ruang gerak anggaran dalam mengalokasi berbagai sumber ekonomi serta mendistribusikannya lebih merata. ${ }^{16}$

Indonesia merupakan wilayah yang mempunyai jati diri, cita-cita, impian, struktur sosial, budaya dan kelembagaan.Indonesia memiliki konstitusi yang memberikan amanah tentang perekonomian berdasarkan atas asas kekeluargaan.Negara Indonesia telah meninggalkan mitos-mitos fundamentalisme pasar yang mengilhami kebijakan ekonomi nasional atau neoliberalisme. Nasionalisme ekonomi dan semangat kemerdekaan serta kedaulatan ekonomi harus selalu relevan dan berkesinambungan satu sama lain. ${ }^{17}$

Karakteristik yang dimiliki ekonomi rakyat sangat beragam, mempunyai cakupannya yang sangat luas dan tergantung jenis kegiatan.Sebagian besar ekonomi rakyat bekerja di luar kerangka legal dan pengaturan (legal and regulatory framework) yang ada. Kelemahan aturan dan kebijakan pemerintah yang ada menjadikan ekonomi rakyat sulit berkembang.Beberapa upaya intervensi yang dilakukan pemerintah sering kali mematikan ekonomi rakyat seperti pengaturan tata niaga. Situasi informalitas sektor ekonomi rakyat menjadikan penyebab matinya kapital ekonomi rakyat atau dengan kata lain tidak dapat dipergunakan untuk kapitalisasi dan traksaksi ekonomi. Rakyat tidak dapat mengakses lembaga keuangan formal dan harus berhubungan dengan sumber pinjaman informal yang mengikat dengan bunga sangat tinggi. ${ }^{18}$

\section{Hasil dan Pembahasan}

Indikator perubahan fluktuatif struktur ekonomi suatu negara terletak pada kesejahteraan masyarakatnya.Terdapat perbedaan konsep kesejahteraan antara pandangan subyektif dan obyektif. Pada dasarnya, kesejahteraan mengutamakan ketentraman, keharmonisan hubungan antar sesama, kemandirian dalam kebersamaan, saling menghormati sesama manusia dan mempertahankan kelestarian alam. Di segala segmen masyarakat harus mentaati setiap ketentuan dan peraturan yang diterapkan dan menegakkan sanksi secara tegas. Kesejahteraan masyarakat tercapai dengan terpenuhinya kebutuhan dasar manusia seperti pangan, sandang dan papan yang layak serta terpenuhinya kebutuhan sekunder dan tersier. Tingkat kesejahteraan dapat diukur dari kepemilikan barang berharga, tersedianya fasilitas umum yang cukup (seperti pendidikan, kesehatan, pasar). Perbaikan kualitas kehidupan dapat dilakukan melalui pengadaan barang-barang konsumsi yang berkualitas dan bahan kebutuhan sehari-hari dalam kuantitas memadai dan harga relatif terjangkau. Proses perbaikan ini berjalan baik dengan mengedepankan kualitas konsumsi menjadi lebih baik, dan seiring berjalannya waktu maka pembangunan ekonomi terlaksana efisien dan terarah serta bermanfaat bagi perbaikan kualitas kehidupan masyarakat.

Badan Pusat Statistik (BPS) mencatat pertumbuhan ekonomi Indonesia pada kuartal I 2020 sebesar $2,97 \%$ year on year (yoy). Pertumbuhan tersebut mengalami kontraksi $2,41 \%$ dibandingkan triwulan IV 2019. Pertumbuhan ekonomi triwulan I 2020 ini lebih rendah dari kuartal I 2019 yoy dan lebih kuartal IV 2019 yang tercatat 4,97\% yoy. Hal ini mengalami perlambatan yang cukup baik dibandingkan periode yang sama tahun lalu, maupun secara kuartal per kuartal dari kuartal terakhir tahun 2019. Penurunan pertumbuhan ekonomi ini disebabkan turunnya sejumlah ekspor Indonesia. Dampak Corona membuat sejumlah negara melakukan lockdown sehingga perdagangan ekspor impor menjadi terhambat.

Pertumbuhan ekonomi Indonesia semakin terpuruk akibat penyebaran virus Covid-19 telah memasuki negara Indonesia. Pada kuartal II, pertumbuhan ekonomi Republik Indonesia minus 5,32\%, merupakan data terburuk sepanjang tahun 2019. Angka pertumbuhan ekonomi

\footnotetext{
${ }^{16}$ Sjahrir.Ekonomi, enak dibaca dan perlu.(Jakarta: Pustaka Utama Grafiti, 1994). Hlm. 110-111.

${ }^{17}$ Hendrawan Supratikno. Ekonomi Nurani vs Ekonomi naluri. (Jakarta: Yayasan Pustaka Obor, 2011). Hlm. 61.

${ }^{18}$ Julius R. Latumaerissa. Perekonomian Indonesia dan Dinamika Ekonomi Global. (Jakarta: Mitra Wacana Media, 2015). Hlm. 393.
} 
ini memburuk dari kuartal 12020 yang mencapai 2,97\% dan kuartal II 2019 mencapai 5,05\%. Kontraksi pertumbuhan ekonomi sebesar 5,32\% merupakan yang terendah sejak triwulan I tahun 1999, pada saat itu ekonomi Indonesia mengalami kontraksi sebesar 6,13\%. Pertumbuhan ekonomi kuartal II adalah tergolong terburuk sejak krisis 1998 yaitu minus pada saat iyu minus 16,5\%. Pada saat kuartal II 2008 lalu, krisis finansial global melanda, pertumbuhan ekonomi masih berada di angka 2,4\%. Secara keseluruhan sepanjang tahun krisis 2008, ekonomi Indonesia masih tumbuh 6,1\%. Pertumbuhan ekonomi kuartal II 2020 ini disebabkan oleh kontraksi di berbagai komponen, terutama di komponen pengeluaran.Pada kuartal II 2020, Badan Pusat Statistik mencatat sebagian besar sektor mengalami pertumbuhan negative. Ada yang masih mengalami pertumbuhan positif antara lain bidang informasi dan komunikasi, jasa keuangan, pertania, real estate, jasa pendidikan, jasa kesehatan dan pengadaan air.

Memasuki kuartal II 2020, pertumbuhan ekonomi Indonesia mulai membaik meskipun masih minus. Pertumbuhan ekonomi masih berada di level negatif merupakan dampak dari pandemi dan berharap pada kuartal II mengalami perbaikan. Pemerintah Indonesia telah memperkirakan yang akan terjadi pada perekonomian nasional sejak pandemi mulai menggerogoti perekonomian China dan beberapa negara di Eropa pada awal pandemi muncul. Belanja pemerintah dalam APBN dan APBD menjadi tulang punggung pertumbuhan ekonomi nasional di tengah pandemi Covid-19 saat ini. Pemerintah tetap meningkatkan belanja terutama dalam mengatasi dampak pandemi yang melanda masyarakat Indonesia, yang mengakibatkan muncul defisit anggaran yang besar. Anggaran negara merupakan tulang punggung kehidupan ekonomi, dengan adanya penerimaan yang menurun harus tetap mempertahankan anggaran belanja negara. Kondisi ini memaksa pemerintah Indonesia untuk menaikkan defisit lebih dari 3\% dengan menerbitkan Peraturan Pemerintah Pengganti Undang-Undang (Perpu) Nomor 1 tahun 2020 tentang kebijakan keuangan negara dan stabilitas sistem keuangan untuk penanganan pandemi corona virus disease (Covid-19), yang kemudian menjadi Undang-Undang No. 02 tahun 2020 yang memberikan izin defisit anggaran lebih dari 3\% terhadap produk domestik bruto (PDB) sampai dengan tahun 2020.

Pertumbuhan ekonomi Indonesia pada kurtal III 2020 diperkirakan berada dia angka minus, mengalami kenaikan sedikit dri kuartal II. Hal ini disampaikan Presiden Joko Widodo setelah menggelar sidang kabinet Senin tanggal 02 November 2020. Perkiraan pertumbuhan ekonomi Indonesia pada kuartal IV menunjukkan tren yang positif, karena ekonomi telah bergerak ke angka yang lebih baik. Angka pertumbuhan ekonomi Indonesia jauh lebih baik dibandingkan negara lain. Pada saat ini, angka konsumsi rumah tangga mencapai minus. Hal ini mengindikasikan agar demand (permintaan) diperkuat sehingga konsumsi meningkat. Kondisi realisasi belanja sedang berada di titik maksimal dan sangat berpengaruh terhadap pertumbuhan ekonomi pada kuartal IV, yng diharapkan membaik dan angka plus. Prediksi pertumbuhan ekonomi bergerak meningkat dan positif akan berpengaruh kepada gerak belanja spending. 
Di ilustrasikan kondisi fluktuatif pertumbuhan ekonomi di tahun 2020 dari kuartal I s/d III, dan prediksi kuartal IV adalah sebagai berikut:

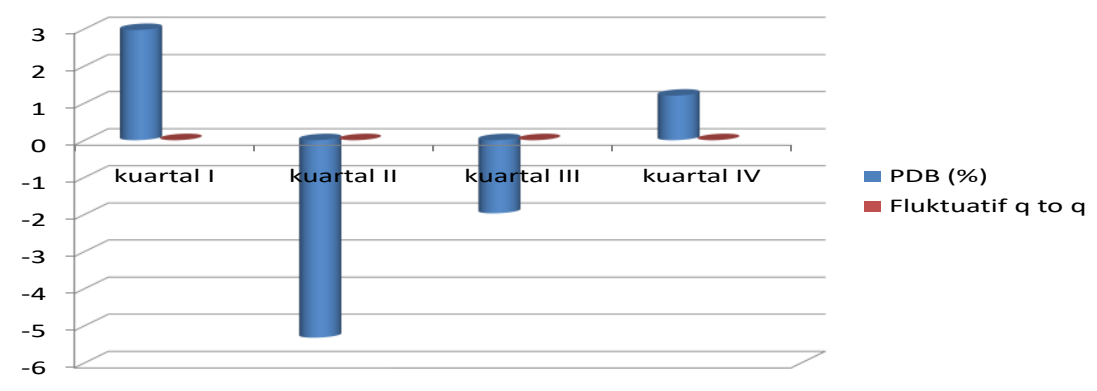

Gambar 1. Pertumbuhan Ekonomi Tahun 2020

Pada penyajian data diatas memperlihatkan bahwa pada kuartal II dan III mengalami pertumbuhan ekonomi yang sulit karena berada pada angka minus. Dari data tersebut diatas, diharapkan dengan adanya peralihan peningkatan positif dari kuartal II ke III meskipun masih berada pada angka minus dapat berpengaruh terjadi peningkatan pada kuartal IV.

Peningkatan produksi mampu merombak struktur ekonomi menjadi ekonomi industri yang efisien. Pencapaian ekonomi yang efisien dengan membentuk keseimbangan supply dan demand. Keseimbangan tersebut dapat terwujud dengan terjadinya quantity demanded dan quantity supplied bersepakat pada titik harga keseimbangan (market equilibrium). Salah satu indikator dalam mengukur market equilibrium adalah harga internasional, yakni adanya perdagangan luar negeri (ekspor dan impor).Dalam mengatasi persoalan ekonomi harus menggunakan market solution.Pembebasan pasar secara fleksibel dan efisien dapat menyumbang kontribusi yang cukup besar pada pertumbuhan ekonomi Indonesia. Pertumbuhan ekonomi yang ingin dicapai dan stabil membutuhkan format kebijaksanaan tetap berupa anggaran berimbang, pengendalian inflasi, pengelolaan neraca pembayaran dan utang luar negeri yang teliti serta hati-hati.

Ada 3 (tiga) proses perubahan struktur ekonomi yaitu akumulasi, distribusi dan alokasi. Perubahan struktur ekonomi menjadi menurun harus segera dilakukan pemulihan antara lain dengan cara penguatan landasan sektor perbankan agar dapat menjalankan fungsinya sebagai lembaga intermediasi. Perlambatan pada sektor finansial akan berakibat pada sektor real yang sangat sulit maju dalam memanfaatkan momentum pemulihan ekonomi karena kelangkaan pengucuran dana. Pertumbuhan ekonomi berada pada level positif harus bertumpu pada pengeluaran pembentukan modal tetap domestik bruto (gross domestic fixedcapital formation). Peran perbankan harus dapat optimal menyalurkan kredit dalam jumlah yang memadai. Sumber pertumbuhan ekonomi yang lain adalah pengeluaran konsumsi rumah tangga, meningkatnya kepercayaan konsumen, kondisi politik dan keamanan yang stabil dan terjaga, meningkatnya kinerja ekspor. 
Gambaran pertumbuhan ekonomi dari tahun 2014 sampai dengan 2020, adalah sebagai berikut:

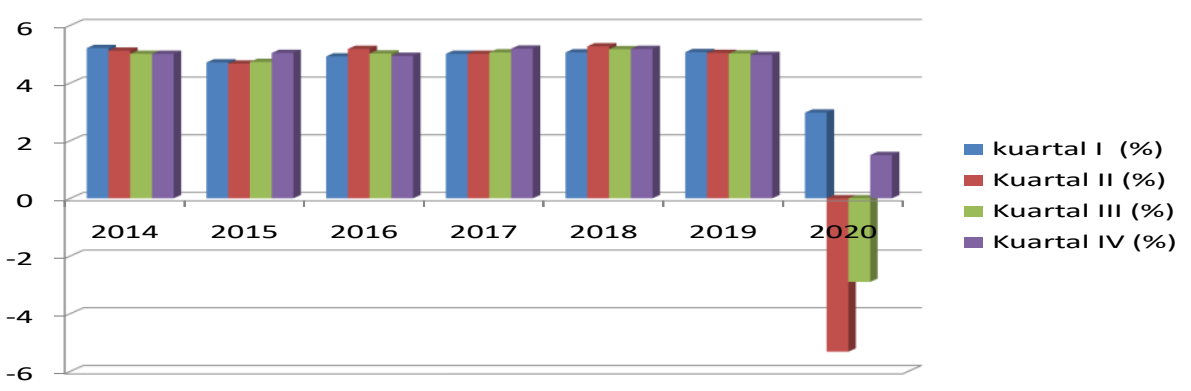

Gambar 2. Pertumbuhan Ekonomi Tahun 2014

Penyajian data pertumbuhan ekonomi dari tahun 2014 sampai dengan 2019 menunjukkan pada kisaran positif dan sangat baik. Pada tahun 2020 mulai menunjukkan kisaran angka negatif memasuki kuartal II dan III. Tahun 2020 mengalami perlambatan ekonomi yang sangat tinggi dan memasuki resesi pada kuartal III karena masih bertumbuh negatif. Prediksi kuartal IV mengalami peningkatan dan dalam angka positif karen adanya perubahan menaik dari kuartal II ke kuartal III.

Peningkatan aktifitas perekonomian yang ditandai oleh kenaikan permintaan agregat, menjadi tekanan terhadap inflasi karena tidak diimbangi oleh penawaran agregat jangka pendek. Banyaknya permasalahan struktural perekonomian, seperti terganggunya fungsi intermediasi perbankan dan masuh rendahnya minat investasi karena faktor resiko yang tinggi. Peningkatan kapasitas terpakai (utilitas) industri harus diiringi penambahan kapasitas terpasang yaitu laju investasi yang belum meningkat secara signifikan. Indikator lain yang menunjukkan tekanan harga berasal dari peningkatan kegiatan perekonomian yang tercermin dari peningkatan harga aset. Pertumbuhan ekonomi dapat meningkat dengan meningkatnya pengeluaran investasi dan ekspor serta kebijakan moneter yang kondusif.

Penguatan ekonomi dilakukan dengan strategi merombak struktur ekonomi yang monopolistik dan anti persaingan menjadi struktur yang lebih adil dan kondusif serta strategi untuk meningkatkan akses kelompok masyarakat miskin terhadap sumber daya. Untuk mewujudkannya perlu upaya yang simultan dan komprehensif sebagai berikut:

1. Memfokuskan investasi di bidang pengembangan sumber daya manusia, terutama pendidikan dasar.

2. Menyusun kebijakan yang mengarah pada stabilitas ekonomi dengan menunjukkan bahwa pertumbuhan ekonomi dapaat tercapai dan hasilnya dapat terdistribusikan pada seluruh lapisan masyarakat secara adil.

3. Menciptakan lingkungan kompetisi yang fair bagi usaha kecil, dengan cara merombak struktur ekonomi yang monopolistic dan anti persaingan.

4. Meningkatkan akses kelompok ekonomi kecil terhadap berbagai sumber daya ekonomi yakni modal, tanah, informasi dan teknologi

5. Melakukan deregulasi terhadap komoditi yang pemasarannya diatur atau dipegang pemerintah.

6. Mengubah bentuk insentif institusional bagi birokrasi di tingkat local, dengan cara memberikan pelayanan perizinan usaha secara gratis, sehingga usaha kecil akan terdorong 
untuk mendaftarkan usahanya dan pemerintah daerah dapat memperoleh peningkatan pajak dari usaha kecil tersebut.

7. Menghapuskan berbagai pungutan bagi usaha kecil.

8. Menghapuskan kredit bersubsidi pada bunga dan membiarkan penyediaan kredit berjalan dengan mekanisme pasar.

9. Mengalihkan subsidi dalam bentuk bantuan biaya operasional untuk institusi yang mempunyai kinerja baik.

10. Mendorong kemungkinan pembentukan lembaga akreditasi nirlaba bagi institusi keuangan yang independen.

11. Meningkatkan transparansi dan accountability.

12. Mendorong penggunaan model skim pembiayaan oleh lembaga perbankan terhadap usaha kecil.

13. Mendorong kemungkinan pembentukan lembaga penjamin bagi usaha kecil untuk pinjaman yang lebih besar, misalnya ke bank.

14. Melonggarkan perizinan pendirian organisasi seperti serikat kerja.

15. Menyediakan lembaga konsultasi untuk membantu masyarakat paling miskin yang dapat merangsang lebih banyak pemberian pinjaman dan dukungan kredit mikro untuk masyarakat yang sangat miskin.

16. Memacu penyediaan lapangan pekerjaan penuh dan produktif serta memperkuat integrase social.

17. Mencabut distorsi kebijakan terhadap produsen pertanian.

18. Melonggarkan peraturan yang membatasi permintaan tenaga kerja.

19. Mendorong investasi pada infrastruktur fisik, penyuluhan pertanian.

Beberapa langkah konkret yang harus dilakukan penyelenggara negara dalam rangka mengurangi beban hutang adalah sebagai berikut:

1. Melakukan kebijaksanaan merubah subsidi harga menjadi target subsidi.

2. Meningkatkan efisiensi pajak dan mendukung kebijaksanaan pajak yang lebih equitable terhadap semua pihak.

3. Pemerintah perlu menyusun strategi yang terkoordinasi dalam masalah penjualan aset negara dan program privatisasi.

4. Mengelola recovery rate yang realistis.

5. Menyusun prosedur penjualan aset yang jelas.

6. Menentukan bahwa tujuan privatisasi dan penjualan aset negara bukan hanya mendapatkan revenue dengan perlunya penjualan aset-aset tersebut.

7. Menyusun rencana privatisasi yang rasional dan konsisten.

8. Pemerintah harus berani dan jujur dan transparan dalam memberikan keterangan tentang kerugian yang dialami dalam proses restrukturisasi.

9. Menyusun aturan penjualan aset yang rasional dan konsisten.

10. Menolak keinginan politis menguasai aset-aset negara yang bertenatangan dengan perlunya penjualan aset-aset tersebut.

11. Melakukan sosialisasi yang efektif untuk mennentukan langkah pemulihan yang kurang popular.

12. Menolak langkah pemerintah melakukan bail out terhadap kewajiban pihak swasta.

13. Pemberantasan korupsi secara menyeluruh.

Pada negara-negara maju, pembangunan ekonomi lebih mengutamakan mekanisme pasar dan mendudukkan pemerintah seminimal mungkin, sedangkan negara-negara di Asia Timur mengasosiasikan kuatnya peran pemerintah, yakni pemerintah dan swasta berinteraksi dalam suatu jalinan kelembagaan yang memungkinkan terpacunya pertumbuhan usaha atau industry yang efisien dan berdaya saing. Ditinjau dari pembangunan fisik, kaum kapitalisme 
dana liberalism telah banyak membuktikan keampuhannya dalam memakmurkan masyarakat. Tolak ukur keberhasilan pembangunan suatu negara tidak hanya dari aspek materi tetapi penguatan harkat dan matabat umat manusia.

Pada tahun 2020 di kuartal I akan berakhir, Indonesia mengalami perubahan ekonomi yang cukup serius, yang merupakan akibat penyebaran virus Covid-19 melanda negara ini. Perekonomian dunia mengalami penurunan akibat masalah pandemic sangat berimbas kepada pertumbuhan ekonomi Indonesia pada kuartal II sehingga mencapai minus 5,23\%. Penyebaran virus Covid-10 mengakibatkan rendahnya harga komoditas, ketidak pastian pasar keuangan, yang mempunyai pengaruh sangat signifikan terhadap kondisi ekonomi global setiap negara yaitu pertumbuhan ekonomi menurun drastis, yang mengakibatkan. Perlambatan pertumbuhan ekonomi Indonesia tidak terlepas dari melambatnya laju pertumbuhan ekonomi di negara-negara maju dan berkembang lainnya. Pertumbuhan ekonomi yang melambat karena proses pemulihan ekonomi yang berjalan tidak sesuai dengan harapan terkait menurunnya kinerja investasi yang mengakibatkan investasi melemah. Investasi yang melemah memperngaruhi lambatnya investasi pada berbagai sektor berkenaan harga komoditas yang cenderung melemah.Investasi yang berjalan melambat dipengaruhi oleh besarnya pembelian properti oleh para investor.

Indonesia masih menghadapi tantangan yang berasal dari dalam negeri, antara lain yaitu tingkat kemiskinan yang masih tinggi, jumlah penduduk yang hidup diatas garis kemiskinan dan masih rentan terhadap goncangan ekonomi, kesenjangan yang cukup tinggi, tingkat pengangguran terbuka yang masih tinggi, kondisi fiscal yang masih dihadapkan pada persoalan belum optimalnya penerimaan negara dan belanja negara, sedangkan tantangan dari luar negeri adalah perlambatan ekonomi global, ketidakpastian di negara Eropa, perubahan politik di Amerika Serikat dan harga komoditas yang masih belum pulih, ditambahn dengan bergejolaknya peningkatan penyebaran virus Covid-19 yang belum dapat ditanggulangi secara maksimal.

\section{SIMPULAN}

Berdasarkan hasil dan pembahasan penelitian, maka peneliti dapat menarik kesimpulan yang berkenaan dengan Perubahan Fluktuatif Struktur Ekonomi Indonesia Pada Masa Pandemi Covid-19 adalah sebagai berikut:

1. Penyebaran Covid-19 mempunyai pengaruh yang sangat signifikan terhadap pertumbuhan ekonomi Indonesia, yakni terlihat pada kuartal II 2020 di angka minus $5,32 \%$, kuartal III masih berada di minus $1 \%$ sampai dengan minus $2,9 \%$. Hal ini mengindikasikan negara Indonesia memasuki kondisi resesi.

2. Pemerintah dan masyarakat Indonesia saling bahu memabahu dalam menanggulangi dampak pandemi ini, dengan melakukan dengan memutus rantai penularan (menemukan orang-orang yang terinfeksi untuk diobati dan diisolasi), langkah selanjutnya secara konsisten menguatkan kebijakan physical distancing sebagai strategi dasar mengatasi pandemi, adanya sinergi kuat antara aparat pemerintah dan masyarakat golongan mampu menyebar bantuan ekonomi ke masyarakat yang membutuhkan terutama lapisan bawah, kurang mampu dan tidak mampu.

3. Pelaksanaan evaluasi tindakan kondusif mengatasi penyebaran Covid-19 di setiap kuartal tahun 2020, terutama pada periode dengan pertumbuhan ekonomi yang masih minus. Pada kuartal IV diharapkan akan mengalami peningkatan pertumbuhan ekonomi kembali normal atau pada kisaran plus. 
Al-Mutharahah: Jurnal Penelitian dan Kajian Sosial Keagamaan

Vol. 17 No. 2. Juli-Desember 2020

\section{DAFTAR PUSTAKA}

Basri, Faisal. Perekonomian Indonesia, Tantangan dan Harapan bagi Kebangkitan Indonesia. Jakarta: Erlangga, 2002.

Kamaluddin, Rustian. Beberapa Aspek Perkembangan Ekonomi Nasional Dan Internasional. Jakarta: Lembaga Penerbit Fakultas Ekonomi Universitas Indonesia, 1989.

Latumaerissa, Julius R. Perekonomian Indonesia dan Dinamika Ekonomi Global. Mitra Jakarta: Wacana Media, 2015.

Mubyarto. Pemberdayaan Ekonomi Rakyat, laporan kaji tindak program IDT. Jakarta: Bappenas, 1999.

Sastra, Eka. Kesenjangan Ekonomi. Mewujudkan Keadilan Sosial di Indonesia. Bandung: PT. Mizan Publika, 2017.

Sjahrir. Ekonomi, enak dibaca dan perlu. Jakarta: Pustaka Utama Grafiti, 1994.

Hendrawan Supratikno. Ekonomi Nurani vs Ekonomi naluri. Jakarta: Yayasan Pustaka Obor, 2011.

Gill, Richard T. Ekonomi Pembangunan Dulu dan Sekarang. Jakarta: Ghalila, 1983. 